Cite this: RSC Adv., 2017, 7, 16878

Received 23rd January 2017 Accepted 12th March 2017

DOI: 10.1039/c7ra01033h

rsc.li/rsc-advances

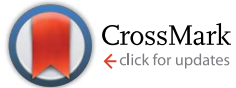

\section{Synthesis of nanocomposites of polypyrrole/ carbon nanotubes/silver nano particles and their application in water disinfection}

\author{
Mohamed Abdel Salam, ${ }^{a}$ Abdullah Y. Obaid, ${ }^{a}$ Reda M. El-Shishtawy*ab \\ and Saleh A. Mohamed ${ }^{\text {cd }}$
}

Contamination of drinking or irrigation water with pathogenic bacteria, such as Escherichia coli (E. coli) and Staphylococcus aureus (S. aureus), is a major global health problem. Nanomaterials have been of growing interest owing to their promising properties as antimicrobial agents. In this study, in situ oxidative polymerization of pyrrole with silver nitrate was employed to obtain nanocomposites materials containing different percentages of single wall carbon nanotubes ( $\left.\mathrm{CNT}_{0-60} / \mathrm{PPy} / \mathrm{AgNPs}\right)$. The reaction proceeds smoothly at room temperature and the silver content was about 80 wt\% of composite. The morphology of composites was determined by transmission electron microscope (TEM) to indicate the formation of core-shell structure in which AgNPs as core and PPy-CNT as shell with observed homogeneity in the nanocomposites. The samples were also characterized by ATR-

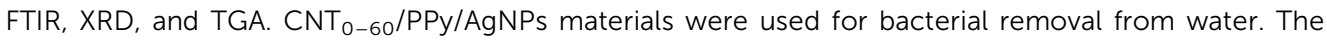
bacterial removal was evaluated using the column filter method. The results indicated that the removal percentage of $E$. coli ranged from $87.5 \%$ to $95 \%$ using $\mathrm{CNT}_{0-20} / \mathrm{PPy} / \mathrm{AgNPs}$. The data obtained in this study indicated that $\mathrm{CNT}_{60} / \mathrm{PPy} / \mathrm{AgNPs}$ nanocomposite was found to be effective towards $E$. coli with $100 \%$ removal, whereas PPy/AgNPs obtained in this work was specific for the complete removal of $S$. aureus (100\%).

\section{Introduction}

Pathogenic bacteria, as a main cause of life-threatening human diseases, which affect millions of people annually, develop resistance against antibiotics and continue challenging scientists globally forcing them to seek other effective alternatives. ${ }^{\mathbf{1 - 5}}$ The ever increasing global demand of pure water free from pathogenic bacteria is pressing scientists for devising new materials useful for water disinfection. Recent studies have indicated that nanoscale materials are promising as effective antimicrobial agents. ${ }^{6-11}$ Nanocomposites are new emerging and promising research route which composed of two or more different materials, one of those materials is in a nanometric dimension. ${ }^{12-14}$ Each of the nanocomposite components has its unique characteristics and upon the formation of the nanocomposite, new advantages, features, and characteristics usually arise. Some enhanced properties, such as significant

\footnotetext{
${ }^{a}$ Chemistry Department, Faculty of Science, King Abdulaziz University, P. O. Box 80200, Jeddah 21589, Saudi Arabia.E-mail: elshishtawy@hotmail.com

${ }^{b}$ Dyeing, Printing and Textile Auxiliaries Department, Textile Research Division, National Research Centre, Dokki, Cairo, Egypt

${ }^{c}$ Biochemistry Department, Faculty of Science, King Abdulaziz University, P. O. Box 80200, Jeddah 21589, Saudi Arabia

${ }^{d}$ Molecular Biology Department, National Research Center, Dokki, Cairo, Egypt
}

mechanical property, ${ }^{15}$ thermoelectric performance ${ }^{16-18}$ and thermal stability, ${ }^{19}$ etc.

Polypyrrole (PPy) is one of the attractive conducting polymers which have been used greatly in nanoscience and nanotechnology due to their exceptional properties such as unique electrical properties, controllable chemical and electrochemical properties, high $\pi$-conjugated polymeric chains, and reversible doping/de-doping process. ${ }^{\mathbf{1 4 , 2 0 , 2 1}}$ The biocidal effect of PPy is likely attributed to its positive charge that would adhere negatively charged bacteria on its surface causing death of bacteria. ${ }^{22-24}$

On the other hand, the high affinity of silver nanoparticles (AgNPs) towards sulfur-containing amino acids on cell membrane and phosphor presents in DNA of bacteria, resulting in disinfection. ${ }^{25-27}$ Recent studies indicated that AgNPs suffer from being applied owing to their instability in aqueous solution, which lead to their aggregation that would decrease their antibacterial activity. ${ }^{28}$ Also, AgNPs in aqueous solution could cause high toxicity to human cells and ecology. It is believed that the cytotoxicity of AgNPs is mainly attributed to the release of silver ions that induce the production of reactive oxygen species. ${ }^{29}$ Therefore, incorporation of AgNPs in a polymer matrix and/or composite materials would synergies the overall biocidal effect and also minimize adverse effects of silver. In 
this interest, PPy/AgNPs were applied as antimicrobial and showed enhanced biocidal effect. ${ }^{23,30}$

Carbon nanotubes (CNTs) ${ }^{31}$ are new emerged and fascinating nanomaterials which have come under intense multidisciplinary study because of their unique physical and chemical properties. CNTs include single-wall (SWCNTs) and multiwall (MWCNTs) depending on the number of layers comprising them. CNTs show the characteristics of unique size distributions, novel hollow-tube structures, high specific surface areas and electrical semi-conductivity and conductivity. These characteristics allow them to be used in a broad range of applications such as catalysts, ${ }^{32}$ different biological aspects $^{33-39}$ and nanoscale electronics. ${ }^{40-42}$ As disinfectants, CNTs proved effectiveness for killing bacteria by causing perturbation and/or disruption of the cell membrane and specific microbial process via oxidation. ${ }^{43}$ Accordingly, development of CNTs/AgNPs composites demonstrates a promising approach for enhanced disinfection. ${ }^{44-46}$

Although there are many research studies devoted to the synthesis and characterization of different nanocomposites based on PPy, CNTs and AgNPs, there is no research work focus on exploring the synthesis of ternary nanocomposites combining the three different nanomaterials; PPy, CNTs and AgNPs and their uses for water disinfection. In this work, different nanocomposites $\left(\mathrm{CNT}_{0-60} / \mathrm{PPy} / \mathrm{AgNPs}\right)$ were synthesized and fully characterized. The potential use of these new materials for the removal of pathogenic bacteria are explored.

\section{Experimental}

\subsection{Materials}

Analytical grade pyrrole, silver nitrate, acetone, single walled carbon nanotubes (CNT) were purchased from Sigma-Aldrich and was used as received. Aqueous solutions were prepared from distilled water.

\subsection{Synthesis}

Different compositions of CNT were made according to the following procedure. In a conical flask containing $80 \mathrm{ml}$ distilled water, $0.6 \mathrm{~g}, 8.94 \mathrm{mmol}$ pyrrole was added and stirred vigorously to get a clear solution. Then appropriate amount of CNT $(0,10,20,40,60 \% \mathrm{w} / \mathrm{w}$ of pyrrole) was mixed with the pyrrole solution with stirring. An aqueous solution of silver nitrate $(3.78 \mathrm{~g}, 22.25 \mathrm{mmol})$ in $20 \mathrm{ml}$ distilled water was added in one portion to the above mixture and the reaction mixture was stirred at room temperature overnight and left stand for a week in dark room and the solids obtained were filtered, rinsed with water four times, acetone two times and dried overnight in an oven at $50{ }^{\circ} \mathrm{C}$. The yield obtained was 3.01, 3.1, 3.21, 3.35, $3.51 \mathrm{~g}$ of PPy/AgNPs, $\mathrm{CNT}_{10} / \mathrm{PPy} / \mathrm{AgNPs}, \mathrm{CNT}_{20} / \mathrm{PPy} /$ AgNPs, $\mathrm{CNT}_{40} / \mathrm{PPy} / \mathrm{AgNPs}$, and $\mathrm{CNT}_{60} / \mathrm{PPy} / \mathrm{AgNPs}$, respectively.

\subsection{Techniques}

Infrared spectra were performed on a were performed on a PerkinElmer spectrum 100 FT-IR spectrometer. All samples were prepared by mixing FTIR-grade $\mathrm{KBr}$ (Aldrich Chemicals) with $1.0 \mathrm{wt} \%$ of the sample and grinding to a fine powder. XRD patterns of the samples were recorded on a D8 Advanced diffractometer (Bruker AXS, Germany) with CuK1 radiation (1.54178 ̊). The operation voltage and current were kept at 40 $\mathrm{kV}$ and $40 \mathrm{~mA}$, respectively. The morphology and size of the nanoparticles were characterized at $100 \mathrm{kV}$ by a JEOL 2010 TEM. Thermogravimetric analysis (TGA) was carried on a Shimadzu TGA-50H thermogravimeter analyzer and the sample was heated from room temperature to $900{ }^{\circ} \mathrm{C}$ at a rate of $10^{\circ} \mathrm{C} \mathrm{min}^{-1}$ in an inert nitrogen atmosphere.

\subsection{Bacterial removal}

2.4.1. Bacteria. E. coli and S. aureus were grown on blood agar for one day at $36^{\circ} \mathrm{C}$. The number of bacteria was determined by bacterial counter.

2.4.2. Column adsorption of bacteria. The bacteria were applied directly to a column $\left(1 \times 1 \mathrm{~cm}\right.$ i.d.) containing $\mathrm{CNT}_{0-60} /$ PPy/AgNPs (200 mg). The adsorbed bacteria were eluted with distilled water at a flow rate of $0.5 \mathrm{ml} \mathrm{min}^{-1}$ and $1 \mathrm{ml}$ fractions were collected.

2.4.3. Statistical analysis. The statistical analyses were performed by a one-way ANOVA and the Student's $t$-test. The results were expressed as means \pm S.D. Difference are considered significant when $P<0.05$.

\section{Results and discussion}

\subsection{Synthesis of $\mathrm{CNT}_{0-60} / \mathbf{P P y} / \mathbf{A g N P s}$}

A major avenue for the production of novel materials is relied on the formation of inorganic-organic nanocomposites in which both functionality would be synergized leading to a new functionality. In this interest, it was envisioned that simultaneous formation of polypyrrole and AgNPs via in situ oxidative polymerization of pyrrole ${ }^{47-49}$ would serve as an intimate way for obtaining nanocomposites with different content of CNT. Scheme 1 shows the formation of intimate nanocomposites with different percentage of CNT.

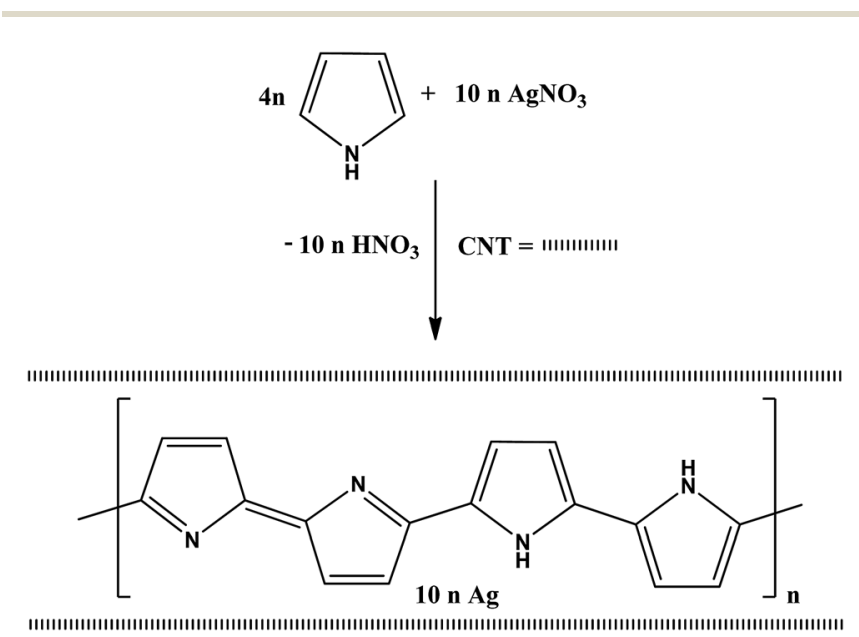

Scheme 1 In situ oxidative polymerization of pyrrole by silver nitrate in the presence or absence of CNT. 


\subsection{FTIR spectra}

Attempts have been made using ATR-FTIR, however, all spectra were appearing with either weak absorption or hidden peaks. Upon trying to redo the FTIR using $\mathrm{KBr}$ method, the peaks in all samples were clearly observed. The FTIR spectra of all samples are shown in Fig. 1. A broad absorption band is shown in the range between 4000 and $2600 \mathrm{~cm}^{-1}$, which could be attributed to $\mathrm{O}-\mathrm{H}$ present in the samples and/or water, $\mathrm{C}-\mathrm{H}$ and $\mathrm{N}-\mathrm{H}$ groups. The absorption band around 1582 and $1630 \mathrm{~cm}^{-1}$ in the CNT spectrum represents the $\mathrm{C}=\mathrm{C}$ bond vibration. ${ }^{50}$ Comparing the intensity of these two bands with the corresponding two bands present in composite samples indicates the overweight of vibrations due to PPy to those resulted from CNT, as the intensity was in an opposite manner.

PPy was made following the oxidative ferric chloride method reported in the literature ${ }^{51}$ so as to compare its FTIR data with PPy made by in situ oxidative polymerization using silver nitrate as oxidant and in the presence of different percentages of CNT.

Interestingly, regardless the CNT content, PPy made in composite didn't show the broad absorption band that observed above $2000 \mathrm{~cm}^{-1}$ for the one made with $\mathrm{FeCl}_{3}$, indicating the absence of intra-chain excitations due to the presence
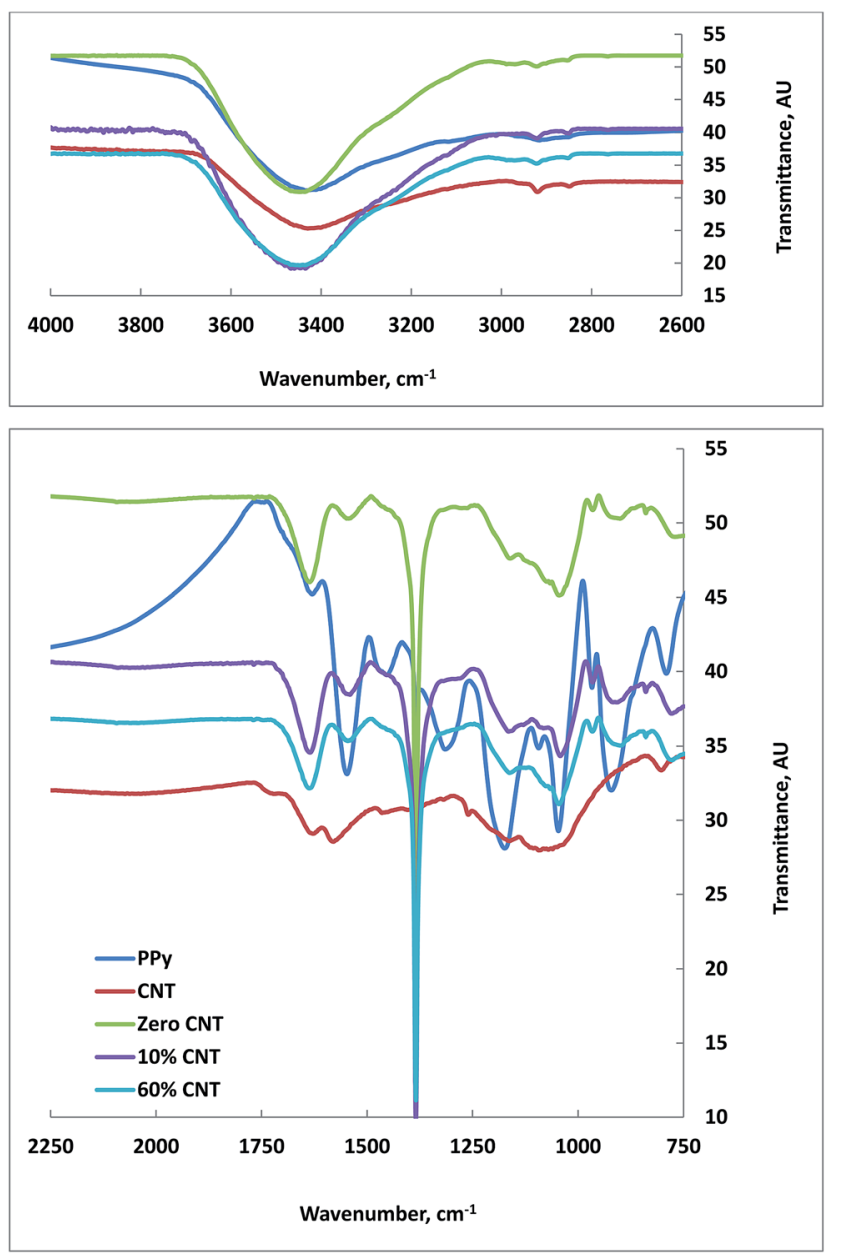

Fig. 1 FTIR of PPy, CNT, CNT $0,10,60 / P P y / A g N P s$. of AgNPs in the composite in core-shell forms. Additionally, PPy alone showed the characteristic peaks at $1632 \mathrm{~cm}^{-1}$ (due to $\mathrm{C}=\mathrm{C}$ and/or $\mathrm{C}=\mathrm{N}$ bond), $1550 \mathrm{~cm}^{-1}$ (likely due the skeletal vibrations involving $\mathrm{C}=\mathrm{C}$ ), $1454 \mathrm{~cm}^{-1}$ (correspond to $\mathrm{C}-\mathrm{N}$ stretching vibration), $1314 \mathrm{~cm}^{-1}$ (due to $\mathrm{C}-\mathrm{H}$ and/or $\mathrm{C}-\mathrm{N}$ inplane deformation), $1173 \mathrm{~cm}^{-1}$ (due to a breathing vibration of the pyrrole ring), $1046 \mathrm{~cm}^{-1}$ (due to $\mathrm{C}-\mathrm{H}$ and/or $\mathrm{C}-\mathrm{N}$ in-plane deformation), $922 \mathrm{~cm}^{-1}$ (due to $\mathrm{C}-\mathrm{H}$ out of plane deformation vibrations of the ring) and $790 \mathrm{~cm}^{-1}$ (due to $\mathrm{C}-\mathrm{H}$ out of plane ring deformation). ${ }^{51-53}$ These aforementioned peaks were either blue shifted from $1632 \mathrm{~cm}^{-1}$ for PPy alone to $1637 \mathrm{~cm}^{-1}$ for PPy in composites or red shifted for the rest of absorption bands together with the disappearance of two peaks corresponding to those appeared at 1454 and $1314 \mathrm{~cm}^{-1}$ in PPy alone, indicating the existence of interactions of PPy with composite components. A striking absorption peak situated at $1386 \mathrm{~cm}^{-1}$ due to nitrate counter anions is a strong evident for the in situ oxidative polymerization of pyrrole with silver nitrate. ${ }^{47}$

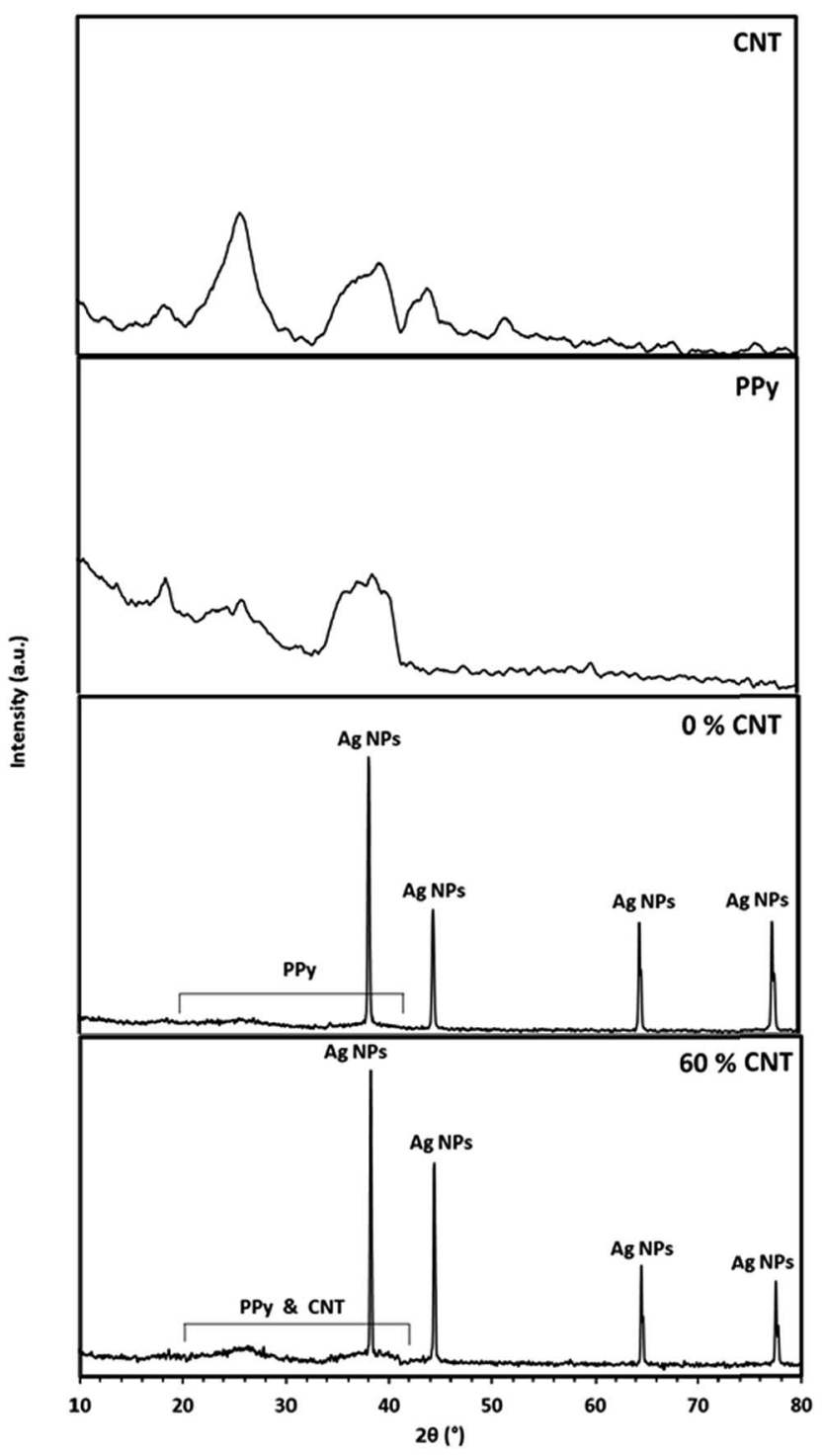

Fig. 2 XRD patterns of CNT, PPy, 0\% CNT and $\mathrm{CNT}_{60} /$ PPy/AgNPs. 


\subsection{XRD analysis}

The XRD patterns of the CNT, PPy, 0\% CNT (PPy/AgNPs nanocomposite), and $60 \% \mathrm{CNT}\left(\mathrm{CNT}_{0-60} / \mathrm{PPy} / \mathrm{AgNPs}\right)$ are shown in Fig. 2. The XRD pattern of pristine CNT shows the peak at $26^{\circ}$ correspond to $\left(\begin{array}{lll}0 & 0 & 2\end{array}\right)$ plane of graphite (JCPDS card no. 75-1621). Meanwhile, the XRD of PPY shows the broad peaks around $2 \theta 20-42^{\circ}$ indicating the presence of PPy in the amorphous form. ${ }^{54}$ The XRD pattern of 0\% CNT (PPy/AgNPs nanocomposite) showed the typical diffraction peaks of silver nanoparticles at $2 \theta=38.2,44.4,64.5,77.5^{\circ}$, corresponding to the cubic, crystalline structure of silver and are assigned to (111), (200), (220) and (311) planes of silver respectively. [JCPDS no. 03-0931], ${ }^{55}$ and broad peak in the region $20^{\circ}$ to $42^{\circ}$ due to the amorphous structure of polypyrrole was observed.
The XRD pattern of $60 \%$ CNT (PPy/AgNPs nanocomposite) showed the typical diffraction peaks of silver nanoparticles at $2 \theta=38.2,44.4,64.5,77.5^{\circ}$, corresponding to the cubic, crystalline structure of silver and are assigned to (111), (200), (220) and (311) planes of silver respectively. [JCPDS no. 03-0931], ${ }^{55}$ and broad peak in the region $20^{\circ}$ to $42^{\circ}$ due to the amorphous structure of polypyrrole was observed indicating a homogeneous involvement of polypyrrole with the AgNPs within the nanocomposite. The XRD pattern of $60 \% \mathrm{CNT}\left(\mathrm{CNT}_{0-60} / \mathrm{PPy} /\right.$ AgNPs) showed the characteristic diffraction peaks of silver nanoparticles in addition to much broad peak in the region $20^{\circ}$ to $42^{\circ}$ due to the presence of both CNT and amorphous polypyrrole was observed indicating a homogeneous dispersion of SWCNT in the composite.
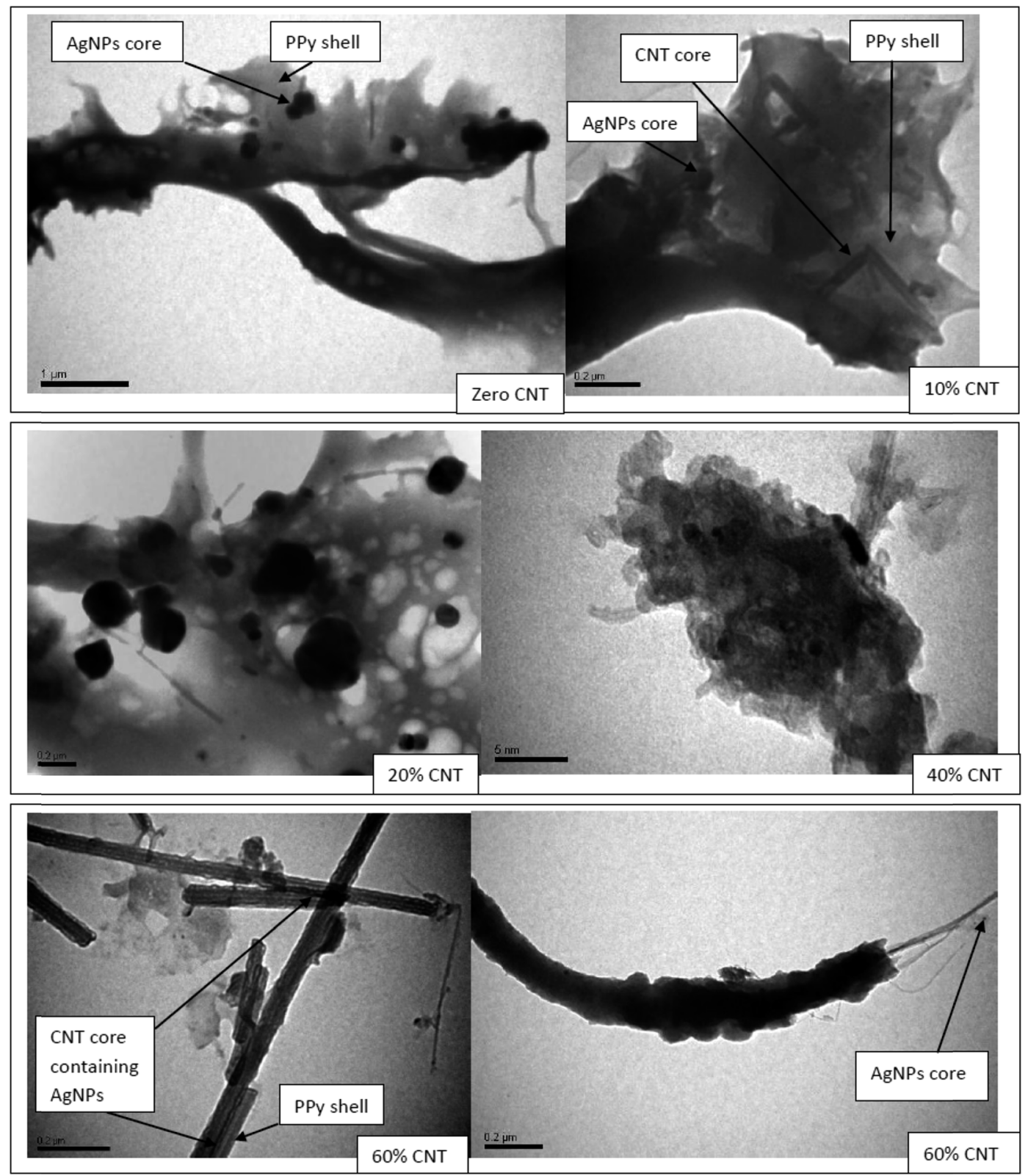

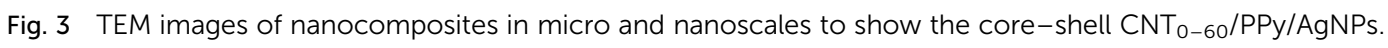




\subsection{TEM}

The oxidative polymerization of pyrrole using silver nitrate as oxidant and pyrrole as reductant results in the formation of PPy/ AgNPs nanocomposites. The morphology and particle sizes of $\mathrm{CNT}_{0-60} / \mathrm{PPy} / \mathrm{AgNPs}$ are shown in Fig. 3. It is generally observed that AgNPs appear as dark spots and coated by PPy matrix in gray color. Also, TEM images show that the PPy/AgNPs nanocomposite has a different morphology from those samples that contain SWCNTs and as the percentage of CNTs increases the morphology turns cylindrical owing to the growing layers of PPy onto CNTs. This result can be explained based on the nucleation sites present in the amorphous layer of CNTs. Accordingly, PPy coated on CNTs while AgNPs are simultaneously produced forming core-shell structures in which AgNPs with or without CNTs are the core and PPy is the shell. Previous studies indicated that the core-shell feature of PPy/SWCNTs could result from charge transfer complex between SWCNTs as an electron acceptor and PPy as electron donor. ${ }^{56}$

\subsection{Thermal analysis}

The thermal stability of polymeric nanocomposite materials are very much affected by the presence of CNTs content. Therefore, it was necessary to reveal such effect and to see whether the results obtained above in TEM images in which the nanocomposites became more intimate with cylindrical morphology (60\% CNT) would be reflected by its thermal stability compared with another lower content (10\% CNT) and PPy/AgNPs.

Fig. 4 shows the TGA of the nanocomposites in absence of CNTs and in presence of different CNT percentages. The thermal stability of zero\% CNTs sample (PPy/AgNPs) reveals a small fraction of weight loss up to $120^{\circ} \mathrm{C}$ due to evaporation of adsorbed water, and weight loss from 150 to $263^{\circ} \mathrm{C}$ attributed to the degradation of small chains of poylpyrrole. Generally, the weight loss below $400{ }^{\circ} \mathrm{C}$ in the presence of CNT could be due to the decomposition of small oligomers of PPy, which are trapped inside CNT, above $400{ }^{\circ} \mathrm{C}$ however, the satiability is higher in the presence of CNT than its absence as a consequence of coiling CNT with PPy and AgNPs. Then a significant weight loss takes place from 400 to $674{ }^{\circ} \mathrm{C}$ owing to the complete

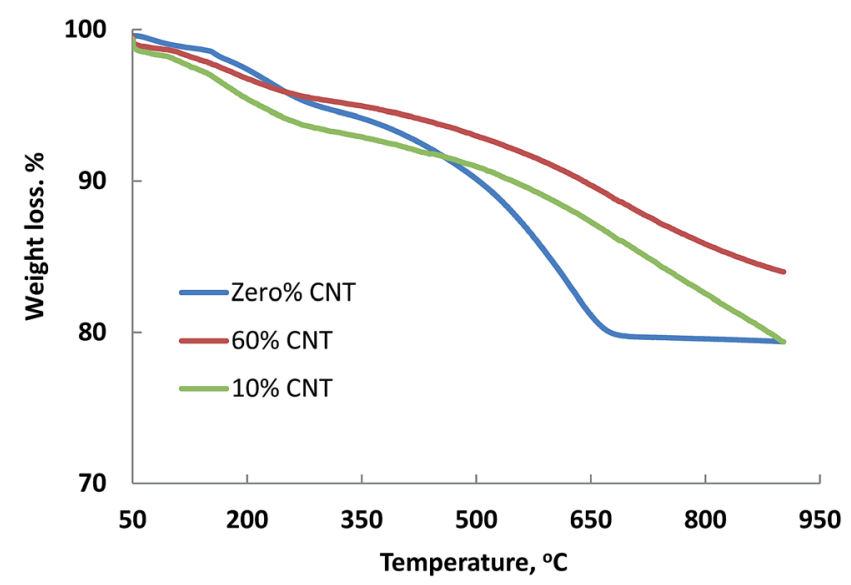

Fig. 4 TGA of $\mathrm{CNT}_{0,10,60} / \mathrm{PPy} / \mathrm{AgNPs}$. degradation of polypyrrole. At this temperature $\left(674{ }^{\circ} \mathrm{C}\right)$, the weight percentage of silver in the PPy/AgNPs nanocomposite can be calculated to be about $80 \%$ of the total weight. The thermal stability of other nanocomposites containing 10 and $60 \%$ was generally better than that of PPy/AgNPs nanocomposite. This stabilization is indicative of CNT-PPy interactions. ${ }^{56,57}$ It is worth mentioning that the silver content as well as the thermal stability for the PPy/AgNPs nancomposite is higher than the previously reported one. ${ }^{58}$

\subsection{Bacterial removal}

Literature data indicate that both AgNPs and polypyrrole alone or in composite form are antimicrobial materials. ${ }^{59,60}$ AgNPs act by attacking the bacterial cell membranes and cause cell death. ${ }^{11}$ Polypyrrole molecule with its positive charge get adhered with the negatively charged cell membrane of bacteria causing microbial growth inhibition. ${ }^{53}$ On the other hand, CNTs possess excellent bacterial inactivation efficiency due to their large surface areas. ${ }^{11}$ Previous studies indicated that batch disinfection of $E$. coli (Gramnegative) were in the order SWCNTs-Ag (70.24\%) > SWCNTs (38.89\%) and for $S$. aureus (Gram-positive) were in the order SWCNTs-Ag $(95.79 \%)>$ SWCNTs $(-131.40 \%)$. The negative number indicted that SWCNTs is not suited by itself for $S$. aureus as the reproduction rate was higher than the disinfection rate. However, SWCNTs-Ag nanocomposite was found effective disinfectant against $S$. aureus compared with $E$. coli as a consequence of the higher affinity of SWCNTs for $S$. aureus accumulation in close proximity with AgNPs. These studies together with the aforementioned literatures prompted us to study the effect of CNTs content in PPy/AgNPs nanocomposites. The different disinfectant behavior of SWCNTs from being active (38.89\%) for $E$. coli and inactive $(-131.40 \%)$ for $S$. aureus was attributed to the difference in cell wall between $E$. coli (slim) and $S$. aureus (deep). ${ }^{\mathbf{4 4}}$ Therefore, it was hypothesized to have all three components in one nanocomposite material by in situ oxidative polymerization of pyrrole with silver nitrate in the presence of different content of SWNT. Filter column method for water disinfection was used as sketched in Fig. 5.

The elution profiles of $E$. coli on $\mathrm{CNT}_{0-60} / \mathrm{PPy} / \mathrm{AgNPs}$ columns are summarized in Table 1 . Twenty thousand bacteria were eluted with columns. For $\mathrm{CNT}_{0-20} / \mathrm{PPy} / \mathrm{AgNPs}$ columns, the

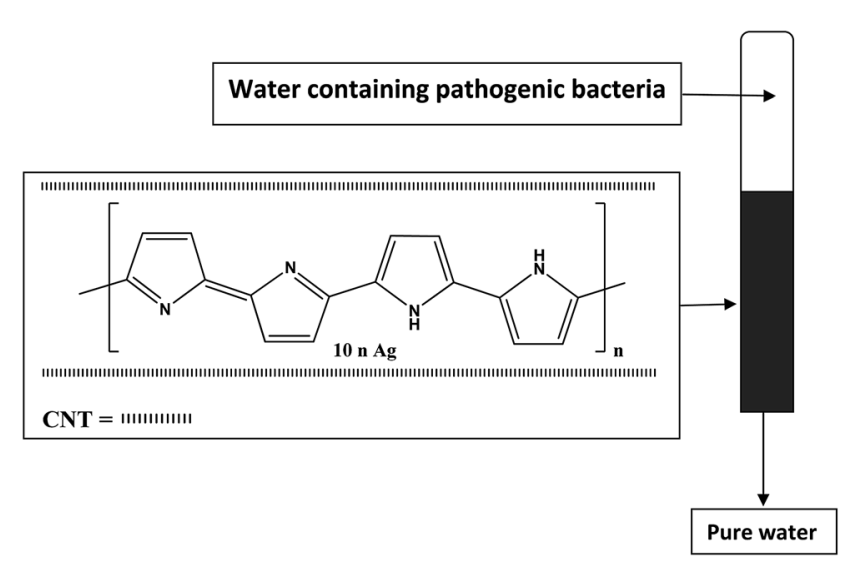

Fig. 5 Filter column method for water disinfection. 
Table 1 A typical elution profile for the chromatography of E. coli on different columns of $\mathrm{CNT}_{0-60} / \mathrm{PPy}_{\mathrm{AgNPs}}{ }^{a}$

\begin{tabular}{|c|c|c|c|c|c|}
\hline \multirow[b]{2}{*}{ Sample } & \multicolumn{5}{|c|}{ Number of bacteria eluted } \\
\hline & Fraction 1 & Fraction 2 & Fraction 3 & Fraction 4 & Fraction 5 \\
\hline $\mathrm{CNT}_{10} / \mathrm{PPy} / \mathrm{AgNPs}$ & 0 & $120 \pm 2.9$ & $252 \pm 4.8$ & $230 \pm 3.1$ & $200 \pm 3.5$ \\
\hline $\mathrm{CNT}_{20} / \mathrm{PPy} / \mathrm{AgNPs}$ & 0 & $193 \pm 4.2$ & $259 \pm 3.6$ & $270 \pm 4.2$ & $150 \pm 3.8$ \\
\hline $\mathrm{CNT}_{40} / \mathrm{PPy} / \mathrm{AgNPs}$ & 0 & $1 \pm 0.02$ & $5 \pm 0.03$ & $3 \pm 0.01$ & 0 \\
\hline
\end{tabular}

${ }^{a}$ The number of bacteria (E. coli) loaded into column is 20000 . Values are presented as means $\pm \operatorname{SD}(n=3)$.

number of eluted bacteria was increased with elution of water and decreased in fractions 4 and 5 . The per cent of adsorbed bacteria ranged from $87.5 \%$ to $95 \%$. Approximately all bacteria were adsorbed by $\mathrm{CNT}_{40-60} / \mathrm{PPy} / \mathrm{AgNPs}$ columns. It is worth mentioning that the effectiveness of removal of $E$. coli appeared just for samples containing $40 \%$ or more per cent of CNT, it seems that enough amount of CNT is necessary for complete removal for the loaded amount of bacteria. This result is nicely in agreement with previous studies which reported that batch disinfection of $E$. coli was $38.89 \%$ using SWCNTs, indicating that CNT posses excellent bacterial inactivation efficiency due to its large surface area. ${ }^{11}$

To further elaborate the antimicrobial effect, a lower load of E. coli (ten thousand) was applied into $\mathrm{CNT}_{10} / \mathrm{PPy} / \mathrm{AgNPs}$ column. Fig. 6 shows a comparative elutions between high and low bacterial load. It is clearly indicated that the elution of bacteria increased with increasing the load of bacteria until the number of bacteria reached to 240 , then started to decline in a comparative manner. From these results it can concluded that the increase of the number of bacteria may be attributed to the overload of the bacteria and the flow rate of the column and during the time of elution the most of bacteria get adsorbed.

Interestingly, $S$. aureus was completely adsorbed by $\mathrm{CNT}_{0-60} /$ PPy/AgNPs columns indicating that PPy/AgNPs obtained in this work is specific for excellent removal of $S$. aureus (100\%). On the other hand, the $\mathrm{CNT}_{60} / \mathrm{PPyAgNPs}$ nanocomposite was found to be effective towards $E$. coli with complete removal (100\%)

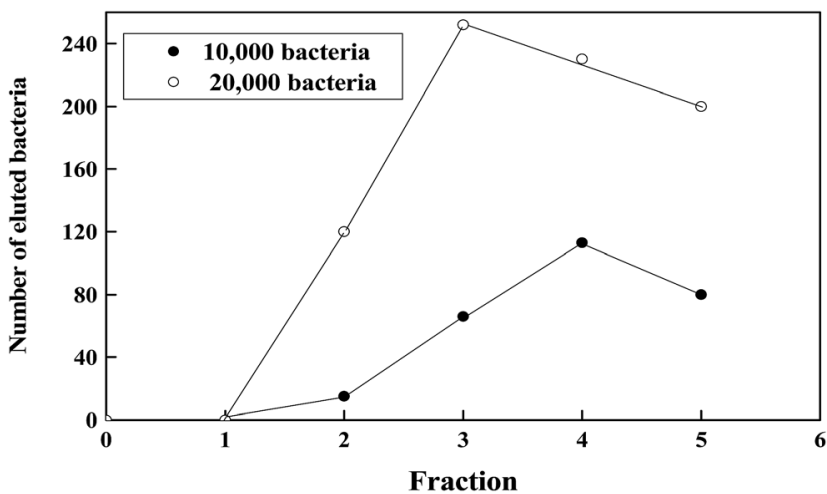

Fig. 6 A typical elution profile for the chromatography of different concentration of $E$. coli on $\mathrm{CNT}_{10} / \mathrm{PPy} / \mathrm{AgNPS}$. indicating an existence of synergistic effect in this nanocomposite.

\section{Conclusions}

$\mathrm{CNT}_{0-60} / \mathrm{PPy} / \mathrm{AgNPs}$ composites have been synthesized in one bath reaction via oxidative polymerization of pyrrole with silver nitrate in aqueous medium and in absence and presence of different CNT\% (w/w based on pyrrole). The TGA data indicated the presence of about $80 \mathrm{wt} \%$ AgNPs in the composite. The morphology of nancomposites indicated an intimacy in the materials produced and the AgNPs appeared as a core shelled by PPy-CNT. Also, the materials were characterized by ATR-FTIR and XRD. The method presented is viable and can be used for the preparation of other organic-inorganic hybrid nanocomposite materials with good homogeneity. The use of these materials for water disinfection was successfully obtained using column filter method.

\section{Acknowledgements}

This project was funded by the Deanship of Scientific Research (DSR), King Abdulaziz University, Jeddah, under grant no. (1433/130/359). The authors, therefore, acknowledge with thanks DSR technical and financial support.

\section{References}

1 K. Vasilev, V. Sah, K. Anselme, C. Ndi, M. Mateescu, B. Dollmann, P. Martinek, H. Ys, L. Ploux and H. J. Griesser, Nano Lett., 2010, 10, 202-207.

2 T. Iwase, Y. Uehara, H. Shinji, A. Tajima, H. Seo, K. Takada, T. Agata and Y. Mizunoe, Nature, 2010, 465, 346-349.

3 K. Roy, G. M. Hilliard, D. J. Hamilton, J. Luo, M. M. Ostmann and J. M. Fleckenstein, Nature, 2009, 457, 594-598.

4 T. Sibanda and A. I. Okoh, Afr. J. Biotechnol., 2007, 6, 28862896.

5 M. H. Kollef, Y. Golan, S. T. Micek, A. F. Shorr and M. I. Restrepo, Clin Infect Dis., 2011, 53(suppl. 2), S33-S55, quiz S56-8.

6 Nano-antimicrobials: progress and prospects, ed. Mahendra Rai, Springer, Berlin, Heidelberg, 2012.

7 N. T. K. Thanh and L. A. W. Green, Nano Today, 2010, 5, 213230. 
8 P. Singh, Y. J. Kim, H. Singh, C. Wang, K. H. Hwang, M. E. Farh and D. C. Yang, Int. J. Nanomed., 2015, 10, 2567-2577.

9 F. Heidarpour, W. A. Wan Ab Karim Ghani, A. Fakhru'l-Razi, S. Sobri, V. Heydarpour, M. Zargar and M. R. Mozafari, Clean Technol. Environ. Policy, 2011, 13, 499-507.

10 A. Zane, R. F. Zuo, F. A. Villamena, A. Rockenbauer, F. A. M. Digeorge, K. Flores, P. K. Dutta and A. Nagy, Int. J. Nanomed., 2016, 11, 6459-6470.

11 S. C. Smith and D. F. Rodrigues, Carbon, 2015, 91, 122-143.

12 R. M. El-Shishtawy, M. A. Salam, M. A. Gabal and A. M. Asiri, Polym. Compos., 2012, 33, 532-539.

13 X. Yang, L. Li and F. Yan, Sens. Actuators, B, 2010, 145, 495500.

14 M. A. Salam, M. S. I. Makki and M. Y. Abdelaal, J. Alloys Compd., 2011, 509, 2582-2587.

15 Z. Hu and G. Chen, Adv. Mater., 2014, 26, 5950-5956.

16 C. Gao and G. Chen, Compos. Sci. Technol., 2016, 124, 52-70.

17 K. Xu, G. Chen and D. Qiu, J. Mater. Chem. A, 2013, 1, 1239512399.

18 M. A. Hussein, R. M. El-Shishtawy and A. Y. Obaid, RSC Adv., 2017, 7, 9998-10008.

19 J. Liu, G. Chen and J. Yang, Polymer, 2008, 49, 3923-3927.

20 C. Merlini, B. S. Rosa, D. Müller, L. G. Ecco, S. D. A. S Ramôa and G. M. O. Barra, Polym. Test., 2012, 31, 971-977.

21 M. A. Chougule, D. S. Dalavi, S. Mali, P. S. Patil, A. V. Moholkar, G. L. Agawane, J. H. Kim, S. Sen and V. B. Patil, Measurement, 2012, 45, 1989-1996.

22 F. A. G. da Silva Jr, J. C. Queiroz, E. R. Macedo, A. W. C. Fernandes, N. B. Freire, M. M. da Costa and H. P. de Oliveira, Mater. Sci. Eng. C, 2016, 62, 317-322.

23 A. Varesano, C. Vineis, C. Tonetti, G. Mazzuchetti and V. Bobba, J. Appl. Polym. Sci., 2015, 132, 41670-41676.

24 A. Varesano, A. Aluigi, L. Florio and R. Fabris, Synth. Met., 2009, 159, 1082-1089.

25 J. Upadhyay, A. Kumar, B. Gogoi and A. K. Buragohain, Mater. Sci. Eng. C, 2015, 54, 8-13.

26 R. V. Ravishankar and B. A. Jamuna, Nanoparticles and their potential application as antimicrobials, in Science against Microbial Pathogens: Communicating Current Research and Technological Advances, ed. A. Méndez-Vilas, Formatex, Badajoz, 2011, pp. 197-209.

27 M. Rai, A. Yadav and A. Gade, Biotechnol. Adv., 2009, 27, 7683.

28 R. Prucek, J. Tuček, M. Kilianová, A. Panáček, L. Kvítek, J. Filip, M. Kolář, K. Tománková and R. Zbořil, Biomaterials, 2011, 32, 4704-4713.

29 Q. H. Tran, V. Q. Nguyen and A.-T. Le, Adv. Nat. Sci.: Nanosci. Nanotechnol., 2013, 4(3), 033001.

30 N. Maráková, P. Humpolíček, V. Kašpárková, Z. Capáková, L. Martinková, P. Bober, M. Trchová and J. Stejskal, Appl. Surf. Sci., 2017, 396, 169-176.

31 S. Iijima, Nature, 1991, 354, 56-58.

$32 \mathrm{X}$. Weilin, L. Changpeng, X. Wei and L. Tianhon, Electrochem. Commun., 2007, 9, 180-184.

33 A. Bianco and M. Prato, Adv. Mater., 2003, 15, 1765-1768.
34 M. G. Zhang, A. Smith and W. Gorski, Anal. Chem., 2004, 76, 5045-5050.

35 P. He and L. Dai, Chem. Commun., 2004, 3, 348-349.

36 I. Heller, J. Kong, H. A. Heering, K. A. Williams, S. G. Lemay and C. Dekker, Nano Lett., 2005, 5, 137-142.

37 M. J. Cloninger, Curr. Opin. Chem. Biol., 2002, 6, 742-748.

38 B. R. Azamian, J. J. Davis, K. S. Coleman, C. Bagshaw and M. L. H. Green, J. Am. Chem. Soc., 2002, 124, 12664-12665.

39 C. McClory, T. McNally, G. P. Brennan and J. Erskine, J. Appl. Polym. Sci., 2007, 105, 1003-1011.

40 T. E. Karakasidis and C. A. Charitidis, Mater. Sci. Eng. C, 2007, 27, 1082-1089.

41 A. B. Dalton, A. Ortiz-Acevedo, V. Zorbas, E. Brunner, W. M. Samson, S. Collins, J. M. Razal, M. Miki Yoshida, R. H. Baughman, R. K. Draper, I. H. Musselman, M. JoseYacaman and G. R. Dieckmann, Adv. Funct. Mater., 2004, 14, 1147-1151.

42 C. K. M. Fung, V. T. S. Wong, R. H. M. Chan and W. J. Li, IEEE Transactions on Nanotechnology, 2004, 3, 395-403.

43 S. Baoukina, L. Monticelli and D. P. Tieleman, J. Phys. Chem. $B, 2013,117,12113-12123$.

44 Y.-N. Chang, J.-L. Gong, G.-M. Zeng, X.-M. Ou, B. Song, M. Guo, J. Zhang and H.-Y. Liu, Process Saf. Environ. Prot., 2016, 102, 596-605.

45 N. X. Dinh, D. T. Chi, N. T. Lan, H. Lan, H. V. Tuan, N. V. Quy, V. N. Phan, T. Q. Huy and A.-T. Le, Appl. Phys. A, 2015, 119, 85-95.

46 N. X. Dinh, N. V. Quy, T. Q. Huy and A.-T. Le, J. Nanomater., 2015, 2015, 814379.

47 M. Omastová, K. Mosnáčková, P. Fedorko, M. Trchová and J. Stejskal, Synth. Met., 2013, 166, 57-62.

48 A. J. Suryawanshi, P. Thuptimdang, J. Byrom, E. Khan and V. J. Gelling, Synth. Met., 2014, 197, 134-143.

49 F. Liu, Y. Yuan, L. Li, S. Shang, X. Yu, Q. Zhang, S. Jiang and Y. Wu, Composites, Part B, 2015, 69, 232-236.

50 I. Montesa, E. Muñoz, A. M. Benito, W. K. Maser and M. T. Martinez, J. Nanosci. Nanotechnol., 2007, 7, 3473-3476.

51 M. Omastová, M. Trchová, J. Kovářová and J. Stejskal, Synth. Met., 2003, 138, 447-455.

52 E. J. Oh, K. S. Jang and A. G. MacDiarmid, Synth. Met., 2002, 125, 267-272.

53 S. Ghosh, G. A. Bowmaker, R. P. Cooney and J. M. Seakins, Synth. Met., 1998, 95, 63-67.

54 L. J. Buckley, D. K. Roylance and G. E. Wnek, J. Polym. Sci., Part B: Polym. Phys., 1987, 25, 2179-2188.

55 S. S. Sana, V. R. Badinni, S. K. Arala and V. K. N. Boya, Mater. Lett., 2015, 145, 347-350.

56 D. N. Huyen, N. T. Tung, T. D. Vinh and N. D. Thien, Sensors, 2012, 12, 7965-7974.

57 B. Zhang, Y. Xu, Y. Zheng, L. Dai, M. Zhang, J. Yang, Y. Chen, X. Chen and J. Zhou, Nanoscale Res. Lett., 2011, 6, 431-439.

58 P. Dallas, D. Niarchos, D. Vrbanic, N. Boukos, S. Pejovnik, C. Trapalis and D. Petridis, Polymer, 2007, 48, 2007-2013.

59 R. M. El-Shishtawy, A. M. Asiri, N. A. M. Abdelwahed and M. M. Al-Otaibi, Cellulose, 2011, 18, 75-82.

60 J. Upadhyay, A. Kumar, B. Gogoi and A. K. Buragohain, Mater. Sci. Eng. C, 2015, 54, 8-13. 